\title{
Halk Sağlığı Gözüyle Koroner Arter Hastalığı ve Sağlık Okuryazarlığı
}

\author{
Coronary Artery Disease and Health Literacy Via Public Health View
}

\section{Asuman Ahcıoğlu' (D)}

${ }^{1}$ Hitit Üniversitesi, Sağlık Bilimleri Fakültesi

\author{
Gulay Yılmazel' ${ }^{10}$
}

\section{Öz}

Koroner arter hastalığı, son 15 yılda küresel olarak en önde gelen ölüm nedeni olmaya devam etmektedir. Hastalık, epikardiyal arterlerde aterosklerotik plak birikimi ile karakterize patolojik bir süreçtir. Bu süreç, koruyucu sağlık hizmetleri düzeyinde yaşam tarzı değişikliği, erken tanı ve farmakolojik tedaviler ile değiştirilebilir. Sağlık okuryazarlığı koroner arter hastalığının önlenmesi ve hastalığın yönetiminde arabulucu işlevi görmektedir. Hastalık tanısı alan bireylerin hastalığın risk faktörlerinden uzak durmaları ve tedavi rejimlerine uymaları gerekmektedir. Bu bireylerde sağlık okuryazarlığı, ilaç talimatlarını, taburcu ve randevu formlarını ve eğitim materyallerini anlama yeteneğinin yanı sıra karmaşık sağlık sistemlerini mütalaa etme yeteneğini içermektedir. Her on koroner arter hastasından biri sınırlı sağlık okuryazarlı̆̆ından muzdariptir. Çağımızın önemli bir halk sağlığı sorunu olan koroner arter hastalığında davranışsal risk faktörlerinin değiştirilmesinde öncelikle riskli grupların taranması ve toplum temelli koroner arter sağlık okuryazarlığının geliştirilmesi yararlı olacaktır. Koroner arter hastalığı ve sağlık okuryazarlığı arasındaki ilişkiyi ortaya çıkaracak çalışmaların artıııması koruyucu sağlık hizmetlerine yeni bir pencere açabilecektir. Bu çalışmada koruyucu sağılk hizmetlerinde koroner arter hastalığının önemi ve sağlık okuryazarlığı ile ilişkisi vurgulanmaktadır.

Anahtar Kelimeler: Koroner Arter Hastalığı, Sağlık Okuryazarlığı, Koruyucu Sağlık, Halk Sağlığı, Hizmetler.

\begin{abstract}
Coronary artery disease remains the leading major cause of death globally over the past 15 years. The disease is a pathological process characterized by atherosclerotic plaque deposition in the epicardial arteries. This process can be changed by lifestyle changes, early diagnosis and pharmacological treatments at preventive health care level. Health literacy acts as a mediator in the prevention and management of coronary artery disease. Individuals diagnosed with the disease should stay away from risk factors of the disease and comply with treatment regimens. Health literacy in these individuals includes the ability to understand drug directions, discharge and appointment forms, and education almaterials, as well as the ability to consider complex health systems. One in ten coronary artery patients suffers from limited health literacy. In order to change behavioral risk factors in coronary artery disease, which is an important public health problem of ourage, it will be beneficial to screen risky groups at first and to improve community - based coronary artery health literacy. Increasing studies to reveal the relationship between coronary artery disease and health literacy may open a new window to preventive health services. This study emphasizes the importance of coronary artery disease in preventive healthcare services and its relationship with health literacy.
\end{abstract}

Keywords: Coronary Artery Disease, Health Literacy, Preventive Health, Public Health, Service. 


\section{GiRiş}

Bulaşıcı olmayan hastalıklar $(\mathrm{BOH})$, dünya genelinde ölüm nedenlerinden biridir. Tüm ölümlerin $\% 71$ 'inden fazlasına kardiyovasküler hastalıklar, kanserler, diyabet ve kronik solunum yolu hastalıklarını içeren dört kronik hastalıktan biri neden olmaktadır (1). Yetersiz sağlık okuryazarığının olumsuz etkisi kronik hastalıklarda belirgin hale gelmektedir. Kronik hastalıklarda azalan hastalık yönetimi, tedaviye zayıf bağlıık, sağlık harcamalarındaki artmış maliyetler yetersiz sağlık okuryazarlığının sonuçları olarak kabul edilmektedir (2-4).

Toplumların yaşlanmasıyla bireylerde bir veya iki kronik sağlık sorunu görülmektedir. Sağlık okuryazarlığı zayıf bireyler, kronik sorunlarını yönetmekte daha fazla zorluk çekmektedirler. Buna yaşam tarzını planlama ve ayarlama ile bilinçli kararlar verme, sağlık hizmetlerine ne zaman ve nasıl erişileceğini bilmek dahildir (4).

Yetersiz sağlık okuryazarlığı gelişmiş ve gelişmekte olan ülkeler açısından bir halk sağlığı sorunudur $(3,5)$. Avrupa Sağlık okuryazarığı Araştırması'nda yer alan 8 ülke (Avusturya, Bulgaristan, Almanya, Yunanistan, İrlanda, Hollanda, Polonya ve İspanya) arasında "mükemmel" sağlık okuryazarlığı kategorisinde en yüksek prevelansın \%25,1 ile Hollanda'ya ait olduğu, "yetersiz" sağlık okuryazarlığı kategorisinde ise en yüksek prevalansın \%26,9 ile Bulgaristan'a ait olduğu gösterilmiştir (3). Türkiye'de ise erișkin nüfusun üçte ikisinden fazlasının yetersiz/sınırlı sağlık okuryazarlığı düzeyine sahip olduğu raporlanmıştır $(5,6)$.

Sağlık okuryazarlığı seviyeleri ile $\mathrm{BOH}$ risk faktörlerinin önlenmesi arasında bir bağlantı vardır. ${ }^{7}$ Türkiye'de $\mathrm{BOH}^{\prime \prime n}$ etkisi artarak devam etmektedir (8). Yapılan çalışmalarda sınırlı sağlık okuryazarığııın BOH'lardaki yaygınlığı ortaya konulmuştur $(7,9)$. Kronik hastalığı olan bireylerde, düşük sağlık okuryazarlığının hastalık yönetiminde yetersizliklere neden olduğu gösterilmiştir $(10,11)$.

Sağlık okuryazarlığı koroner arter hastalığı (KAH)'nın önlenmesi ve yönetiminde önemli bir komponenttir. Koroner arter hastalarının, çoklu yaşam biçimi değişikliğini yerine getirme, risk faktörlerini kontrol altında tutma, tedavi önerilerine uyum sağlama, hastalıklarının öz-yönetimine aktif bir şekilde katıım gösterebilmesinde sağlıkla ilgili bilgiyi anlama becerisine sahip olması beklenmektedir (12). İsveç'te yapılan bir çalışmada düşük sağlık okuryazarlığı daha yüksek kardiyovasküler hastalık risk skorları ile ilişkili bulunmuştur (13).

Bu çalışmada koruyucu sağlık hizmetlerinde koroner arter hastalığının önemi ve sağlık okuryazarlığı ile ilişkisi vurgulanmaktadır.

\section{KORONER ARTER HASTALIĞI}

Koroner arter hastalığı, epikardiyal arterlerde aterosklerotik plak birikimi ile karakterize patolojik bir süreçtir. Bu süreç; yaşam tarzı değişikliği, farmakolojik tedaviler ve hastalık stabilizasyonu için tasarlanmış invaziv müdahalelerle değiştirilebilir. Hastalık klinik olarak sessiz dönemlerde bile kronik, çoğunlukla ilerleyici ve dolayısıyla ciddi tabloya sahiptir (14). Ateroskleroz ile arterlerin duvarlarında lümen içine kolesterolden zengin plaklar birikir ve kan akışı zorlaşır. Kan damarlarında elastikiyet azalır. Zamanla, plak yırtıması sonucunda trombüs meydana gelebilir (15).

Anjina veya göğüs ağrısı, KAH'ın en yaygın semptomudur (16). Birçok insan için, KAH'ın ilk ipucu kalp krizidir. Kalp krizlerinin çoğu, göğsün merkezinde birkaç dakikadan fazla süren rahatsız edici baskı, sıkma, dolgunluk veya ağrı ile hissedebilir. Üst vücudun diğer bölgelerinde belirtiler mevcuttur. Belirtiler bir veya iki kolda, sırt, boyun, çene veya midede ağı veya rahatsızlık içerebilir. Nefes darlığı da en sık görülen belirtilerdendir. Diğer olası işaretler soğuk terleme, bulantı veya baş dönmesi şeklindedir (14).

\subsection{Koroner Arter Hastalığının Epidemiyolojisi}

Sessiz katil olarak adlandırılan $\mathrm{KAH}$, son 15 yılda küresel olarak önde gelen ölüm nedeni olmaya devam etmektedir. Dünya Sağlık Örgütü (DSÖ)'nün 2018 yılı verilerine göre global düzeyde mortalite oranı \%16,6 olarak belirtilmiştir. Türkiye'nin de içinde bulunduğu Avrupa Bölgesinde mortalite oranları ise \%25,4'tür (1).

Türkiye'de hastalık yükü sıralamasında ilk sırada iskemik kalp hastalıkları yer almaktadır (8). Türkiye İstatistik Kurumu (TÜIK) Ölüm Nedeni İstatistikleri 2018 sonuçlarına göre Türkiye'de ölümlerin \%38,4'ü dolaşım sistemi hastalıklarına bağlı olarak gerçekleşmiştir. Dolaşım sistemi hastalıkları nedeniyle gerçekleşen ölümlerin \%39,7'si iskemik kalp hastalığı nedenlidir (17).

\subsection{Koroner Arter Hastalığında Komorbiditeler}

En önemli kronik durumlardan biri olan KAH birden fazla kronik hastalığı olan hastalarda mevcut en yaygın durumlar arasında yer almaktadır (18). Genellikle birden fazla komorbid durumla ortaya çıkan KAH'ın tipik olarak hipertansiyon, hiperlipidemi, diyabet, artrit ve tiroid hastalığı ile birlikte görüldüğü belirtilmiştir (19). KAH olan yetişkinlerde yüksek komorbidite prevalansının olduğu ve komorbiditeler arttıkça hastaneye 30 gün içinde geri kabul oranlarının da giderek arttığı saptanmıștır (20). 


\subsection{Koroner Arter Hastalığında Risk Faktörleri}

Ateroskleroz etyolojisinde davranışsal ve metabolik risk faktörlerinin kilit rol oynadığına dair bilimsel kanıtlar vardır (15). Bu davranışsal ve metabolik risk faktörleri çoğu zaman aynı hastada kombinasyon halinde bulunur ve sinerjistik olarak hareket eder, tek bir hastada miyokard infaktüsü (MI) ve inme gibi akut vasküler olayların genel riskini arttırır. Ateroskleroz sürecini uyaran risk faktörleri şu şekilde gruplandırılmıştır $(14,15)$ :

\section{Davranışsal risk faktörleri}

- Tütün kullanımı

- Fiziksel aktivite eksikliği

- Sağlıksız beslenme (çok fazla tuz, yağ ve kalori)

- Alkolün kullanımı

\section{Metabolik risk faktörleri}

- Artmış kan basıncı (hipertansiyon)

- Artmış kan glukozu (diyabet)

- Yüksek kan lipitleri (kolesterol)

- Fazla kiloluluk ve obezite

\section{Diğer risk faktörleri}

- Yoksulluk ve düşük eğitim düzeyi

- İleri yaş

- Cinsiyet

- Genetik

- Psikolojik faktörler (örneğin, stres, depresyon)

- Artmış homosistein düzeyi

\subsubsection{Davranışsal Risk Faktörleri}

\section{Tütün Kullanımı}

Dünya'da tütün kullanım yaygınlığının \%20 olduğu ve tütün kullanımının küresel düzeyde kalp ve damar hastalıklarının \%10'nuna yol açtığı tahmin edilmektedir (15,21). Küresel Yetişkin Tütün Araştırması 2016 sonuçlarına göre Türkiye'de 19,2 milyon kişi $(\% 31,6)$ halen tütün ürünü kullanmaktadır (22). Tütün kullanımının aterogenezis gelişimini tetiklemesiyle endotel disfonksiyonu, inflamasyon, protrombozis, lipid metabolizmasında değişiklikler görülmekle beraber kalp hızı vazokonstrüksiyon ve kardiyak output artar (23).

\section{Fiziksel Aktivite Eksikliği}

Dünya Sağlık Örgütü'ne göre 18 yaş ve üzeri yetişkinlerin dörtte birinden fazlasında fiziksel aktivite yetersizliği mevcuttur. Yüksek gelirli ülkelerde fiziksel hareketsizlik düşük gelirli ülkelere göre iki kat daha fazladır. Küresel olarak kadınlar erkeklerden daha az aktiftir. Türkiye'de 18 yaş ve üzerindeki bireylerin yaklaşık üçte biri fiziksel açıdan inaktiftir $(1,21)$.

Fiziksel aktivitenin koroner olayları ve mortalite riskini azalttığı gösterilmiştir (15). Fiziksel aktivite, vazodilatasyonu ve kan damarlarındaki vazomotor fonksiyonu geliştirir. Egzersiz kapasitesinin arttırılması, $\mathrm{KAH}$ olan erkek ve kadınlar arasında sağkalımın artırılmasında bağımsız bir gösterge olarak bulunmuştur (24). Düzensiz olarak yapılan boş zaman fiziksel aktiviteleri de $\mathrm{KAH}$ tanısı olanlar arasında mortalite riskini azaltmaktadır (25).

Koroner arter hastaları için yeterli fiziksel aktivite önerileri haftanın beş günü 30-60 dakika orta yoğunluklu aerobik aktivitesidir (14).

\section{Sağlıksız Beslenme}

Doymuş yağ, trans yağ, kolesterol ve tuzun diyetle fazla alımı ile sebze, meyve, balığın az tüketimi kalp ve damar hastalıkları riskini artırmaktadır (1). Kardiyovasküler risk olan obezite, beslenme ve fiziksel inaktivite ile yakından ilişkilidir. Türk Hipertansiyon ve Böbrek Hastalıkları Derneği (THBHD)'nin 2012 yılında Tuz Tüketimi ve Gıda Kaynakları Çalışması SALTurk 2 çalışmasında ülkemizde günlük tuz tüketimi 14,8 gr olarak saptanmıştır (26).

Sağlıklı beslenme sağlıklı vücut ağırlığına, lipit profilinde ve kan basıncında beklenen düzeye katkı sağlayabilir $(15,21)$. Koroner arter hastaları için meyve, sebze, baklagiller, lif, çoklu doymamış yağlar, kabuklu yemişler ve balıklar bakımından zengin bir Akdeniz beslenme modeli benimsenmektedir (27). Kalp ve damar hastalıklarının önlenmesine destek için günlük tuz alımının kişi başına 5 gramdan az olması önerilmektedir (15).

\section{Alkolün Kullanımı}

Alkol tüketiminin $\mathrm{KAH}$ üzerindeki etkisi tüketimin düzeyine ve örüntüsüne bağlıdır. Orta düzeyde alkol tüketimi HDL kolestrol düzeyi, trombolitik profil ve trombosit agregasyonu üzerine yararlı etkileri vardır. Alkolün kullanımı, hipertansiyon, akut $\mathrm{MI}$, kardiyak aritmi ve inme ile ilişkilidir $(1,15,21,28)$. Alkolün haftada 100 gramdan fazla tüketimi MI riskini artırmakta ve diğer kardiyovasküler hastalıklar mortalitesi ile ilişkilendirilmektedir (29).

Türkiye Sağlık Araştırması 2016 yılı verilerine göre alkol kullanım oranı \%12,2'dir. Alkol kullanım oranı erkeklerde \%19,3 kadınlarda \%5,3 olarak raponlanmıştır. ${ }^{30}$ Kadınlar günde 10 gram, erkekler günde 20 gramdan fazla içmemelidir (16). 


\subsubsection{Metabolik Risk Faktörleri}

\section{Artmış Kan Basıncı (Hipertansiyon)}

Yüksek kan basıncı, koroner kalp hastalığı için major risk faktörüdür (19). Dünya genelinde 2014 yllında 18 yaş ve üzeri kişilerde yüksek kan basıncı $(140 \geq 90 \mathrm{mmHg})$ prevalansı \%22'dir (1).

Türk Hipertansiyon Prevalansı Çalışması 2 (PatenT2) sonuçlarına göre Türkiye'de hipertansiyon prevalansı $\% 30,3$ olup, bu oran erkeklerde $\% 28,4$ ve kadınlarda \%32,3 bulunmuştur (31). Kan basıncının düşürülmesi, kardiyovasküler hastalık riskini önemli ölçüde azaltabilmektedir (32).

\section{Artmış Kan Glikozu (Diyabet)}

Kronik bir hastalık olan diyabet, pankreasın yeterince insülin üretememesinden veya üretilen insülinin vücutta yeterince etkili kullanılamamasından kaynaklanır (21). Her iki durumda da artmış kan glikozu kalp ve kan damarlarını etkiler, kalp krizinin olası komplikasyonlarındadır (28).

Dünya Sağlık Örgütüne göre 2014 yılında dünya çapında artmış kan glikozu prevelansının \%9 olduğu tahmin edilmektedir (28). Türkiye'de 2010 yllında diyabet prevalansının ise \%13,7'ye yükseldiği saptanmıştır (33).

\section{Yüksek Kan Lipitleri}

Lipoproteinlerin içerisinde; LDL "kötü", HDL ise "iyi" kolesterol olarak bilinir ve bunlara ilaveten trigliseritler de yer almaktadır. Düşük LDL kolesterol seviyesi vasküler sağlık için daha iyidir. HDL kolesterol, LDL kolesterolü arter duvarlarından çıkararak vasküler hastalıklara karşı korumaktadır (15). Türk halkının kanda total kolesterol düzeyleri batılı toplumlar ile karşılaştıııldığında genelde düşük olarak bulunmuştur (34).

Yüksek kan kolesterolü kalp krizi ve inme riskini arttırmaktadır. Yüksek serum kolesterolünde \%10'luk düşüşün 40 yaşındaki bir erkekte 5 yıl içinde kalp hastalığı riskini \%50 azalttığı tespit edilmiştir (15).

\section{Aşırı Kilo Ve Obezite}

Enerji alımı ve enerji tüketimi arasındaki dengesizlik obezitenin başlıca nedenidir. Aşırı kilo ve obezite kan basıncı, kolesterol, trigliseritler ve insülin direnci üzerinde olumsuz metabolik etkilere neden olmaktadır (15). Türkiye Beslenme ve Sağlık Araştırması'na göre yetişkin bireylerde obezite görülme sıklığı \%30,3 olarak tespit etmiştir (35).

Abdominal obezitenin bir göstergesi olan bel çevresi kardiyovasküler hastalık ve diyabet gelişimi ile güçlü bir şekilde ilişkili bulunmuştur. Bel çevresi erkekler için $\leq 94 \mathrm{~cm}$ ve kadınlar için $\leq 80 \mathrm{~cm}$ önerilmektedir (14).

\subsubsection{Diğer Risk Faktörleri}

\section{Yoksulluk Ve Düşük Eğitim Düzeyi}

Gelir dağılımı veya eğitim düzeyi gibi sosyal belirleyiciler, genel olarak sağlığı olduğu kadar kardiyovasküler sağlığı da dolaylı olarak etkilemektedir ve risk faktörlerine maruz kalmayı artırmaktadır (15). Koroner arter hastalığında insidans veya risk faktöründe düşük gelir ve düşük eğitimin birlikte olması tek başına yoksulluğun olması ya da düşük eğitimin olmasından daha güçlü bir ilişkiye sahiptir (36).

\section{İleri Yaş}

Artan yaşla birlikte, artmış kollajen elastin içeriğindeki azalma ile karekterize, damar duvar yapısındaki değişiklikler sistolik kan basıncında artışa, diyastolik kan basıncında azalmaya yol açmaktadır (37).

Kalp hastalığı, herhangi bir yaşta başlayabilmekle birlikte en belirgin olarak 40 yaşından sonra artmaktadır (16).

\section{Cinsiyet}

Koroner arter hastalığı, erkeklerde yaygın görülen bir hastalık olmasına rağmen 1990'ların sonunda kadınların hastalığı olarak görülmeye başlanmıştır. Bu farklııı beslenme örüntüsünde, yeme davranışlarında ve beslenme inanışlarındaki araştırmalarla ortaya koyulmaya çalışılmıştır (15).

Cinsiyete bağı mortalite farklılıkları, özellikle 60 yaşın altındaki genç hastalarda belirgin olarak ortaya çıkmıştır ve her iki cinsiyet arasında mortalite farkları azalmıştır (38).

\section{Genetik}

Epidemiyolojik ve aile temelli çalışmalarda KAH'da genetiğin rolü \%40-60 arasındadır. Genom çapında birleşme çalışmalarını mümkün kılan tek nükloitid polimorfizmlerinin mikro dizilerinin mevcudiyeti $\mathrm{KAH}$ için 33 genetik risk varyantının keşfeldilmesine yol açmıştır. Bu varyantlardan 23'ü bilinmeyen mekanizmalar yoluyla KAH'na yol açar, $\% 10$ 'u ise hipertansiyon ve lipidlerle ilişkilidir (39).

\section{Psikolojik Faktörler}

Koroner hastalığı olan bireylerde depresyon, anksiyete ve mental stres sık karşılaşılan bir sorundur (40). Depresyon, kalp hastalığı olan kişiler arasında yaygın olarak görülmektedir. Stres, KAH hastaları için anlamlı bir risk faktörü olarak bulunmuş ve hastaların stres seviyeleri yüksek tespit edilmiştir (41). 
Avrupa Kardiyoloji Derneği yayınlamış olduğu son kılavuzunda psikososyal risk faktörleri için değerlendirme yapılmasını önermektedir. Psikolojik ve farmakolojik müdahaleler ile kardiak rehabilitasyonun depresyon, anksiyete ve stres üzerinde yararlı bir etkiye sahip olabileceği düşünülmektedir (14).

\section{Artmış Homosistein Düzeyi}

Serum homosistein düzeyleri $\mathrm{KAH}$ şiddeti ile yakından ilişkilidir. Homosistein aterosklerotik oluşumun erken belirleyicisi olarak görülmektedir. İlerleyen yaş, erkek cinsiyet, sigara içimi, kahve tüketimi, yüksek kan basıncı, istenmeyen lipid profili, yüksek kreatinin ve sağlıksız beslenme artmış homosistein düzeyleri ile ilişkili faktörlerdir (42).

\subsection{Koroner Arter Hastalığında Erken Tanı Ve Tedavi}

Koroner arter hastalığı açısından şüphelenilen hastada temel testler standart laboratuvar biyokimyasal testi, Elektrokardiyogram (EKG) izlemi, istirahat ekokardiyografi ve göğüs röntgenini içermektedir (14).

Biyokimyasal Testler: Laboratuar araştırmaları, iskeminin olası nedenlerini, kardiyovasküler risk faktörlerini, ilişkili durumlarını ve prognozu belirlemek için kullanılır $(14,43)$.

Elektrokardiyogram (EKG): Kalp atışının elektriksel aktivitesini, hızını ve düzenini ölçmektedir $(14,43)$.

Ekokardiyografi: Ekokardiyogramda kalbin görüntüsünü oluşturmak için ultrason kullanılmaktadır $(14,43)$.

Göğüs Röntgeni: KAH'a eşlik eden pulmoner problemleri olan hastalarda veya atipik göğüs ağrısının başka bir nedenini ekarte etmek için de kullanılmaktadır (14).

Egzersiz Stresi Testi: Bir koşu bandında yürürken kalp atış hızını ölçmektedir. Bu, daha fazla kan pompalamak zorunda kaldığında kalbin ne kadar iyi çalıştığını belirlemeye yardımcı olmaktadır $(14,43)$.

Kalp Kateterizasyonu: Kalbe ulaşmak için bacak, kol veya boyundaki bir arterden ince, esnek bir tüp takarak arterlerin içindeki tıkanıklığı kontrol etmeye yarar $(14,43)$.

Koroner Anjiyogram: Koroner arterlerde tıkanma ve kan akışı izlenir ve X ışınları kullanılmaktadır $(14,43)$.

Koroner Arter Kalsiyum Taraması: Koroner arterlerde kalsiyum ve plak birikimini inceleyen bilgisayarlı tomografi (BT) taramasıdır $(14,43)$.

Koroner arter hastalığı tanısı doğrulandıktan sonra, farmakolojik tedavi ve revaskülarizasyonu içeren uygun tedaviler başlatılmaktadır (14).

\section{Farmakolojik Tedavi:}

Koroner arter hastalarında medikal ilaç tedavisinde kullanılan bazı ilaçlar şu şekildedir $(14,44)$.

- Antikoagülan: Yeni trombüslerin oluşumunu ve mevcut trombüslerin genişlemesini önlemek için kullanılır.

- Antiplatelet Ajan: Kan trombositlerinin birbirine yapışmasını önleyerek kan pıhtılarının oluşmasını önler.

- Anjiyotensin-Dönüştürücü Enzim (ACE) İnhibitörü: Anjiyotensin II seviyelerini düşürerek kan damarlarını genişletir ve direnci azaltır.

- Beta Bloker: Kalp atış hızını ve kardiyak debiyi azaltır.

- Kombine Alfa Ve Beta Bloker: Hipertansif kriz yaşayan hastalar için intravenöz (IV) damla olarak kullanılır.

- Kolesterol Düşürücü İlaçlar: Kanda kolesterol seviyesini düşürürler, statinler ilk en iyi tedavi şeklidir.

- Vazodilatör: Kan damarlarını gevşetir ve iş yükünü azaltırken kalbe kan ve oksijen tedarikini artırır.

- Diüretikler: İdrar yoluyla vücuttaki fazla sıvı ve sodyumdan atılımına neden olur. Kalbin iş yükünü hafifletmeye yardımcı olur.

\section{KORONER ARTER HASTALIĞINDA SAĞLIK OKURYAZARLIĞININ YERI}

Sağlık okuryazarlığı; okuryazarlıkla ilişkili olarak, yaşam kalitesini yükseltme ve sürdürme çabaları doğrultusunda günlük yaşamda sağlık hizmetleri, hastalıkların önlenmesi ve sağlığın geliştirilmesi ile ilgili kararlar almak amacıyla, sağlık bilgisine erişme, sağlık bilgisini anlama, değerlendirme ve kullanma için gerekli olan bilgi, motivasyon ve yeterliliktir (45). Sınırlı sağlık okuryazarlığı koruyucu ve geliştirici sağlık hizmetlerine ve hastalık tespiti faaliyetlerine daha az katılım (mamografi çektirme, grip aşısı yaptırma), riskli sağlık davranışlarını (daha yüksek sigara içme oranları gibi) daha fazla sergileme, daha fazla iş kazası ile ilişkilidir $(2,4)$. Düşük sağlık okuryazarlığ artmış morbidite ve mortalite riski ile ilişkilidir (2).

Koroner arter hastalığı tanısı olan bireylerin çoklu tedavi ve beslenme rejimlerine uymaları gerekmektedir. Bu bireylerde sağlık okuryazarlığı; ilaç talimatlarını, taburcu ve randevu formları ile eğitim materyallerini (örneğin; beslenme rehberleri) anlama yeteneğinin yanı sıra karmaşık sağlık sistemlerini mütalaa etme yeteneğini içermektedir (46). 
Diğer kronik hastalıklarda olduğu gibi kardiyovasküler hastalıklarda da yetersiz sağlık okuryazarlığının getirdiği olumsuz etkiler görülmektedir. Sistematik bir derleme çalışmasında düşük sağlık okuryazar bireylerin daha fazla kardiyovasküler hastalık komorbiditesine sahip olduğu görülmüştür. Sürekli olarak hastane geri kabulleri, düşük yaşam kalitesi, zayıf sosyal destek ve yüksek kaygı düzeyleri koroner arter hastalarında düşük sağlık okuryazarlığa ile ilişkilendirilmiştir (12).

Danimarka'da yapılan bir çalışmada her on koroner arter hastasından birinin sağlıkla ilgili bilgileri anlamayı zor bulduğu ve sağılıkla ilgili bilgileri anlamada güçlük çeken bireylerin yüksek tedavi yükünden muzdarip olduğu gösterilmiştir (47).

Yeterli sağlık okuryazarlığı hastaların yanlış ilaç kullanımından kaçınmasına, çoklu ilaçları yönetmesine, talimatlara göre ilaçlarını almasına, sonuçları etkileyebilecek yan etkileri değerlendirmesine ve hangi semptomların KAH'tan kaynaklanabileceğini anlamasına katkı sağlamaktadır (48).

\section{SONUÇ VE ÖNERILER}

Koroner arter hastaları tekrarlayan kardiyovasküler olaylar açısından yüksek risk altındadır. Farmakolojik ve invazif tedavi yöntemlerindeki ilerlemelere rağmen, risk faktörleri kardiyovasküler mortalitenin belirleyicileri olmaya devam etmektedir. Kardiyovasküler hastalıkların gelişiminde dört davranışsal risk faktörü önemli role sahiptir. Bu faktörler tütün kullanımı, sağlıksız beslenme, fiziksel inaktivite ve aşıı alkol tüketimidir. Davranışsal risk faktörlerinin etkisi artmış kan basıncı, kan glikoz düzeyi, lipid düzeyleri ve obezite varlığında açığa çıkmaktadır. Yaşam biçimi değişikliğini ve risk faktörlerinin kontrolünü içeren primer korunma önlemleri ile hastalığa bağlı ölümlerin bir kısmının önlenebileceği bildirilmektedir (15).

Koruyucu sağlık hizmetleri, sadece hastalığın akut ve kronik durumları için değil, aynı zamanda sağlığın teşviki ve hedeflenen yaşam tarzı tavsiyeleri için de bir dizi hizmeti kapsar. Aile hekimliği uygulamaları, koroner arter hastalığının hem önleyici hem de kronik düzeyde bakımının sağlandığı birinci basamak sağlık hizmetinin bir parçasıdır. Aile hekimlerinin bireylere yaşam tarzı önerileri, toplum düzeyinde sağlığı geliştirme girişimlerinin yanında yer alır ve tüm nüfusun genel sağlı̆ıını iyileştirmeyi amaçlar.
Erken tanı sekonder korunmada bir anahtardır. Laboratuar incelemeleri, kardiyovasküler risk değerlendirme tabloları, kan basıncı ölçümleri hastalı̆ı̆ı erken tanısında yararıdır. Bireylerin birinci basamak sağlık kuruluşlarında, işyerlerinde ve toplumsal alanlarda taranması erken tanıda kullanılan bir yaklaşımdır (15).

Tersiyer korunma önlemleri arasında hastanın eski yaşamına döndürülmesini amaçlayan kardiyak rehabilitasyon programı yer alır. Bu programın içeriği koruyucu sağlık hizmetlerinin amacı ile paraleldir $(49,50)$ :

- Fiziksel aktivitenin teşviki, sağlıklı beslenme önerileri, ilaçların düzenli alınması ve sigarayı bırakmaya yardımcı olacak davranışlar ve sağlıklı yaşam hakkında eğitim verilmesi

- Reinfarktüslerin ve kardiyovasküler mortalitenin önlenmesi için rutin taramaların yapılması ve yıllık influenza aşısının önerilmesi

- Stresi azaltmak ve zihinsel sağlığı iyileştirmek için danışman desteği

Koroner arter hastalığından korunmada koruyucu sağık hizmetlerinin toplumsal düzeydeki uygulamaları ise şu şekilde sıralanabilir:

- Koroner arter hastalığının önemli bir sorun olduğu konusunda farkındalığı artırmak

- Risk gruplarının taranması

- Sigara kullananlarda bırakmayı teşvik edici davranışsal müdahaleler ve danışmanlık

- Yetişkinlik döneminde optimal vücut ağırlığının korunması

- Bireylerin fiziksel aktiviteye teşvik edilmesi

Çağımızın önemli bir halk sağlığı sorunu olan koroner arter hastalığında davranışsal risk faktörlerinin değiştirilmesinde toplum temelli koroner arter sağlık okuryazarlığının geliştirilmesi yararlı olacaktır. Koroner arter hastalığı ve sağlık okuryazarlığı arasındaki ilişkiyi ortaya çıkaracak çalısmaların artırıması koruyucu sağık hizmetlerine bir pencere açabilecektir.

Çıkar Çatışması: Bulunmamaktadır. 


\section{KAYNAKLAR / REFERENCES}

1. World Health Organization. Noncommunicable diseases country profiles, 2018. https://www.who.int/nmh/countries/2018/tur_ en.pdf?ua=1. Erişim tarihi: 18.01.2020

2. Berkman ND, Sheridan SL, Donahue KE, Halpern DJ, Crotty K. Low health literacy and health outcomes: an updated systematic review. Ann Intern Med 2011; 155(2): 97-107.

3. Sørensen K, Pelikan JM, Röthlin F, Ganahl K, Slonska Z, Doyle $G$, et al. Health literacy in Europe: comparative results of the European health literacy survey (HLS-EU). Eur J Public Health 2015; 25(6): 1053-1058.

4. World Health Organization. Health literacy: The solid facts, 2013. https://apps.who.int/iris/bitstream/handle/10665/128703/ e96854.pdf Erişim tarihi:25.12.2019

5. Okyay P, Abacıgil F. Türkiye sağlık okuryazarlığı ölçekleri güvenilirlik ve geçerlilik çalışması. Avrupa Sağlık Okuryazarlığı Ölçeği Türkçe Uyarlaması (ASOY-TR) 2016; Mayıs, 24-41.

6. Tanrı̈ver MD, Yıldıım HH, Ready FND, Çakır B, Akalın HE. Sağlik okuryazarliği araştirmasi, 2014.http://www.sagliksen.org.tr/cdn/ uploads/gallery/pdf/8dcec50aa18c21cdaf86a2b33001a409. pdfErişim tarihi: 27.12.2019

7. Yılmazel G, Çetinkaya F. Relation between health literacy levels, hypertension awareness and control among primary-secondary school teachers in Turkey. AIMS Public Health 2017; 4(4): 314325.

8. T.C.SağlıkBakanlığı.Ulusal Hastalık Yükü Çalışması (UHYÇ), 2013. http://www.hips.hacettepe.edu.tr/UHYCSunumu_06122016.pdf Erişim tarihi: 25.03.2020

9. Teleş M, Kaya S. Kardiyoloji Polikliniğine Başvuran Hastalarda Sağlık Okuryazarlığının Değerlendirilmesi. Hacettepe Sağlık İdaresi Dergisi 2019; 22(4): 711-748.

10. Al Sayah F, Qiu W, Johnson JA. Health literacy and healthrelated quality of life in adults with type 2 diabetes: a longitudinal study. Quality of Life Research 2016; 25(6): 1487-1494.

11. Darvishpour J, Omidi S, Farmanbar R. The relationship between health literacy and hypertension treatment control and followup. Caspian Journal of Health Research 2016; 2(1): 1-8.

12. de Melo Ghisi GL, da Silva Chaves GS, Britto RR, Oh P. Health literacy and coronary artery disease: A systematic review. Patient Educ Couns 2018; 101(2): 177-184.

13. Lindahl B, Norberg M, Johansson $\mathrm{H}$, Lindvall $\mathrm{K}, \mathrm{Ng} \mathrm{N}$, Nordin M, et al. Health literacy is independently and inversely associated with carotid artery plaques and cardiovascular risk. Eur J Prev Cardiol 2020; 27(2): 209-215.

14. Knuuti J, Wijns W, Saraste A, Capodanno D, Barbato E, FunckBrentano C, et al. 2019 ESC Guidelines for the diagnosis and management of chronic coronary syndromes: The Task Force for the diagnosis and management of chronic coronary syndromes of the European Society of Cardiology (ESC). Eur Heart $\mathrm{J}$ 2020; 41(3): 407-477.

15. World Health Organization. Global atlas on cardiovascular disease prevention and control. Geneva: World Health Organization, 2011. http://apps.who.int/iris/bitstream/ 10665/44701/ 1/9789241564373_ eng.pdf?ua=1 Erişim tarihi: 20.02.2020

16. Centers for Disease Control and Prevention. Heartdisease risk factors. https://www.cdc.gov/ heartdisease/coronary_ad.htm Erişim tarihi: 23.03.2020

17. Türkiye İstatistik Kurumu. Ölüm Nedeni İstatistikleri, 2018. http://www.tuik.gov.tr/ PreHaberBultenleri.do?id=30626 Erişim tarihi:13.02.2020
18. World Health Organization. Global Health Centre, Graduate Institute Geneva. WHO Meeting Geneva .Health Literacy - Stepping Up Impact, 2017. http://origin.who.int/globalcoordination-mechanism/working-groups/hl_kickbusch.pdf Erişim tarihi: 23.01.2020

19. Murray MIK, Thalmann IN, Mossialos EA, Zeiher AM. Comorbidities of Coronary Heart Disease and the Impact on Healthcare Usage and Productivity Loss in a Nationally-Based Study. Epidemiology (Sunnyvale) 2018; 8(347): 2161-1165.

20. Forman DE, Maurer MS, Boyd C, Brindis R, Salive ME, Horne FM, et al. Multimorbidity in older adults with cardiovascular disease. $J$ Am Coll Cardiol 2018; 71(19):2149-2161.

21. World Health Organization. Health Statistics and Information Systems.Global Healt Estimates 2016 Summary Tables: Global Death by Cause, Age and Sex, 2000-2016, 2018. https://www. who.int/healthinfo/global_burden_disease/GHE2016_Deaths_ Global_2000_2016.xls?ua=1 Erișim tarihi: 20.02.2020

22. Global Adult Tobacco Survey - Turkey. Fact Sheet Turkey 2016. https://nccd.cdc.gov/ GTSSDataSurveyResources/Ancillary/ DownloadAttachment.aspx?ID=3452 Erişim tarihi: 26.02.2020

23. Roy A, Rawal I, Jabbour S, Prabhakaran D. Tobacco and Cardiovascular Disease: A Summary of Evidence. In Cardiovascular, Respiratory, and Related Disorders. 3rd edition 2017; The International Bank for Reconstruction and Development/The World Bank.

24. Bruning RS, Sturek M. Benefits of exercise training on coronary blood flow in coronary artery disease patients. Prog Cardiovasc Dis 2015; 57(5): 443-453.

25. Lahtinen $M$, Toukola $T$, Junttila $M J$, Piira $O$. P, Lepojärvi $S$, Kääriäinen $\mathrm{M}$, et al. Effect of changes in physical activity on risk for cardiac death in patients with coronary artery disease. Am J Cardiol 2018; 121(2): 143-148.

26. Erdem Y, Akpolat T, Derici Ü, Şengül Ş, Ertürk Ş, Ulusoy Ş. et al. Dietary sources of high sodium intake in Turkey: SALTURK II. Nutrients 2017; 9(9): 933.

27. Wang $X$, Ouyang $Y$, Liu J, Zhu M, Zhao G, Bao W, et al. Fruit and vegetable consumption and mortality from all causes, cardiovascular disease, and cancer: systematic review and doseresponse meta-analysis of prospective cohort studies. BMJ 2014, 349: 4490.

28. World Health Organization. Ambient air pollution: A global assessment of exposureand burden of disease, 2016. https://apps. who.int/iris/bitstream/handle/10665/250141/9789241511353eng.pdf?sequence $=1$ \&isAllowed $=y$ Erişim tarihi: 15.01.2020

29. Wood AM, Kaptoge S, Butterworth AS, Willeit P, Warnakula $\mathrm{S}$, Bolton $\mathrm{T}$, et al. Risk thresholds for alcohol consumption: combined analysis of individual-participant data for 599 912 current drinkers in 83 prospective studies. The Lancet 2018; 391(10129): 1513-1523.

30. T.C. Sağlık Bakanlığı. Sağlık İstatistikleri Yıllı̆ı 2018. https:// dosyasb.saglik.gov.tr/ Eklenti/36134,siy2018trpdf.pdf?0 Erişim tarihi: 03.03.2020

31. Türk Hipertansiyon ve Böbrek Hastalıkları Derneği. Türk Hipertansiyon Prevalans Çalışması PatenT2, 2012. www. turkhipertansiyon.org/ppt/PatenT2.ppt Erişim tarihi:12.01.2020 
32. Ettehad D, Emdin CA, Kiran A, Anderson SG, Callender T, Emberson $\mathrm{J}$, et al. Blood pressure lowering for prevention of cardiovascular disease and death: a systematic review and meta-analysis. The Lancet 2016; 387(10022): 957-967.

33. Satman I, Omer B, Tutuncu Y, Kalaca S, Gedik S, Dinccag N, et al. Twelve-year trends in the prevalence and risk factors of diabetes and prediabetes in Turkish adults. Eur J Epidemiol 2013; 28(2):169-180.

34. Onat A, Can G, Yüksel H, Ademoğlu E, Erginel-Ünaltuna N, Kaya A ve ark.TEKHARF 2017 Tıp Dünyasının Kronik Hastalıklara Yaklaşımına Öncülük. Onat A, İstanbul, 104. http://file.tkd.org.tr/ PDFs/TEKHARF-2017.pdf Erişim tarihi:18.03.2020

35. T.C. Sağlık Bakanlığı. Türkiye Beslenme ve Sağlık Araştırması 2010: Beslenme durumu ve alışkanlıklarının değerlendirilmesi sonuç raporu. Sağlık Bakanlığı Sağlık Araştırmaları Genel Müdürlüğü, Ankara, 2014. (s. 565). https://hsgm.saglik.gov.tr/ depo/birimler/saglikli-beslenme-hareketli-hayat-db/Yayinlar/ kitaplar/diger-kitaplar/TBSA-Beslenme-Yayini.pdf Erişim tarihi: 04.03.2020

36. Lewis MW, Khodneva Y, Redmond N, Durant RW, Judd SE, Wilkinson LL, et al. The impact of the combination of income and education on the incidence of coronary heart disease in the prospective Reasons for Geographic and Racial Differences in Stroke (REGARDS) cohort study. BMC Public Health 2015; 15(1): 1312.

37. Camici G. G, Liberale L. Aging: the next cardiovascular disease? Eur Heart J 2017; 38(21):1621-1623.

38. Cenko E, Yoon J, Kedev S, Stankovic G, Vasiljevic Z, Krljanac $G$, et al. Sex differences in outcomes after STEMl: effect modification by treatment strategy and age. JAMA Intern Med 2018; 178(5): 632-639.

39. Roberts R, Stewart AF, Genes and coronary artery disease: where are we? J Am Coll Cardiol 2012; 60(18): 1715-1721.

40. Kutlu R, Özberk D, I Demirbaş N. Kardiyoloji yoğun bakım ünitesinde yatan hastalarda anksiyete ve depresyon sıklığı ve etki eden faktörler. Türk Göğüs Kalp Damar Cerrahisi Dergisi 2016; 24(4): 672-679.

41. Kurd B. J, Dar M. I, Shoaib M, Malik L, Aijaz Z, Asif I. Relationship between stress and coronary heart disease. Asian Cardiovasc Thorac Ann 2014; 22(2): 142-147.

42. Shenoy V, Mehendale V, Prabhu K, Shetty R, Rao P. Correlation of serum homocysteine levels with the severity of coronary artery disease. Indian J Clin Biochem 2014; 29(3): 339-344.

43. Centers for Disease Control and Prevention. Coronary Artery Disease (CAD), 2019. https://www.cdc.gov/heartdisease/ coronary_ad.html Erişim tarihi: 02.10.2019.

44. American Heart Association. Treatment of a HeartAttack .Types of medications, 2019. https://www.heart.org/en/healthtopics/heart-attack/treatment-of-a-heart-attack Erişim tarihi: 15.10.2019

45. Sørensen K, Van den Broucke S, Fullam, J, Doyle G, Pelikan J, Slonska Z, et al. Health literacy and public health: a systematic review and integration of definitions and models. BMC Public Health 2012; 12(1): 80.

46. Evangelista LS, Rasmusson KD, Laramee AS, Barr J, Ammon SE, Dunbar S, et al. Health literacy and the patient with heart failure-implications for patient care and research: a consensus statement of the Heart Failure Society of America. J Card Fail 2010; 16(1): 9-16.
47. Friis $\mathrm{K}$, Lasgaard $\mathrm{M}$, Pedersen $\mathrm{MH}$, Duncan $\mathrm{P}$, Maindal $\mathrm{HT}$. Health literacy, multimorbidity, and patient-perceived treatment burden in individuals with cardiovascular disease. A Danish populationbased study. Patient Educ Couns 2019; 102(10): 1932-1938.

48. Magnani JW, Mujahid MS, Aronow HD, Cené CW, Dickson VV, Havranek E, et al. Health literacy and cardiovascular disease: fundamental relevance to primary and secondary prevention: a scientific statement from the American Heart Association. Circulation 2018; 138(2): e48-e74.

49. Centers for Disease Control and Prevention. How Cardiac Rehabilitation Can Help Heal Your Heart, 2020. https://www. cdc.gov/features/cardiac-rehabilitation/index.html Erişim tarihi:25.02.2020

50. Hebsur S, Vakil E, Oetgen WJ, Kumar PN, Lazarous DF. Influenza and coronary artery disease: exploring a clinical association with myocardial infarction and analyzing the utility of vaccination in prevention of myocardial infarction. Rev Cardiovasc Med 2019; 15(2): 168-175. 